УДК 7.79.791(045)

DOI: https://doi.org/10.51209/platform.1.3.2021.141-165

Сфрем Олексійович БІТКІНЕ,

незалежний дослідник,

Київ, Україна,

e-mail: artplatforma88@gmail.com,

ORCID: 0000-0003-4396-4849

\title{
ЕКСЦЕНТРИЧНА АКРОБАТИЧНА ПАРА ЯК ФЕНОМЕН СУЧАСНОГО ЦИРКОВОГО МИСТЕЦТВА (НА ПРИКЛАДІ ДУЕТУ «DUO FLASH»)
}

Анотація: Сучасне циркове мистецтво України історично пов'язане 3 діяльністю i акробатів-скоморохів, i перших професійних артистів циркових труп. Особливе місце посідають акробатичні пари. Окремо виділимо саме ексцентриків, коміків. Неоціненним досвідом для молодого покоління циркових артистів в акробатичному жанрі $\epsilon$ досягнення братів Олександра та Василя Ялових, подружжя Пастухових, братів Маренкових, братів Дякових та ін. Вони стояли біля витоків циркового акробатичного мистецтва ще радянської України. Спорт i мистецтво цирку завжди доповнювали один одний у розвитку акробатики як у манежі, так i на спортивних майданчиках. Тісний зв'язок спостерігається і в творчій діяльності сучасних циркових артистів-акробатів, а саме, серед стрибунів у групових номерах, чоловічих та змішаних парах, жіночих трійках або в чоловічих четвірках, в інших видах акробатичного жанру. На сьогодні $є$ багато прикладів саме акробатичних шоу або вистав у світовому цирковому мистецтві.

Акробатична вистава в цирку є актуальною та сучасною формою видовища. Головною дієвою особою вистави є артистакробат, який володіє різними видами цього жанру. Вистава за своєю формою може бути дивертисментом, шоу, ревю, виставою $з$ драматургічним сюжетом. 
До найзначніших феноменів сучасного українського циркового мистецтва сьогодні можна віднести акробатичноексцентричну пару «Duo Flash», яка має понад 20 років історіï. Дует $€$ не тільки самостійним явищем циркового простору України, але i має особливе значення для позиціонування сучасного українського цирку за межами країни, тобто виконує важливу функцію покращення іміджу України у світовому культурному полі, $є$ інструментом побудови міжкультурного діалогу. Учасниками дуету $є$ Єфрем Біткіне та Євген Дашківський, представники циркових династій, випускники Київської муніципальної академії естрадного та циркового мистецтв. Дана розвідка присвячена основним періодам їх творчої біографії (київському, німецькому іспанському), становленню як акробатичної пари, взаємозбагаченню традицій різних циркових шкіл на їх прикладі.

Ключові слова: циркове мистецтв, акробатика, ексцентрика, акробатична пара, фестиваль, режисер, тренер

Вступ. Акробатична вистава в цирку є актуальною та сучасною формою видовища. Головною дієвою особою вистави є артист-акробат, який володіє різними видами цього жанру. Вистава за своєю формою може бути дивертисментом, шоу, ревю, виставою $з$ драматургічним сюжетом. Поява канадської компанії «Цирку Дю Солей», іiі діяльність у галузі відродження традиційних циркових жанрів у сучасному вирішенні, спонукали циркове товариство усього світу, в тому числі й України, на пошуки нових форм циркових вистав.

Постановка проблеми. Складовою видовищного дійства мандруючих циркових труп, у балаганах, у стаціонарних цирках часто 3 давнини ставали виступи акробатів. Вони мали успіх у глядачів, бо то була демонстрація надприродних людських можливостей. Захоплювали акробатичні стрибки вперед або назад через голову, перевороти вперед та назад 3 опусканням у шпагати, ходіння на руках у стійці, колеса та кульбіти. Арсенал акробатичних вправ збагачувався залежно від природних здібностей та фантазії 
виконавців. Особливо вражали «гутаперчеві» хлопчики (клішники) та «каучук», які демонстрували неабияку гнучкість, рухливість суглобів у різних положеннях тіла. Виступи акробатів-одинаків із часом підготували умови для виникнення пар, трійок, груп виконавців. Уже 3 сер. XVII ст. з'явились майстри акробатики, які навчали різним вправам та сприяли появі нових напрямків та форм акробатики [5].

Об'єднання акробатів у пари стало життєвою необхідністю: у багатьох випадках гастролюючі трупи формувалися 3 членів однієї сім’ї. 3 метою урізноманітнити програму кожен з них мав сольні, парні і групові виступи. 3 появою силової акробатики утвердилась і форма іiі демонстрації - силова акробатична пара. Для неї характерні стійки «руки в руки», «рука в руку», стійка верхнього двома руками або однією на голові нижнього, стійка верхнього головою на голові нижнього, перекати нижнього з утриманням верхнього в стійці. При виконанні вправ використовується прийом жимом, що потребує фізичної сили та витривалості [11, с. 27-28].

Аналіз останніх досліджень і публікацій. У вітчизняному циркознавстві зокрема і гуманітаристиці загалом на сьогодні немає окремих праць, наукових розробок, присвячених феномену акробатичної пари у цирковому мистецтві. Існує не дуже розлогий корпус літератури зарубіжних з питань історії цирку (штудії 3. Гуревича [1], Д. Жандо, Ю. Дмитрієва [4; 5], Р. Славського, ін.), але українські дослідники лише нещодавно почали приділяти увагу циркознавчим штудіям, це переважно культурологічні, мистецтвознавчі, педагогічні розробки (дисертаційні дослідження Г. Курінної, М. Малихіної, О. Пожарської, С. Шумакової [12], статті Ю. Романенкової [9-13; 16], Д. Шарикова. Окремої уваги заслуговують праці самих артистів цирку, які добре знються на актуальних проблемах галузі, але i пробують свої сили у теорії: Т. Гріньє, Л. Шевченко, ін.

Мета статті - актуалізація феномену акробатичної пари в контексті циркового мистецтва сучасності на прикладі вітчизняного дуету «Duo Flash». 
Виклад основного матеріалу. Цирковий артист не обмежений у виборі виду діяльності, в якій зв'явиться на манежі. Головним чинником, який спонукає до того чи іншого вибору, стає фахова підготовка артиста. Отже, стати в пару або знайти гідного партнера, верхнього чи нижнього, - неабияка відповідальна задача. Акробатична пара, зрозуміло, складається 3 двох виконавців. Кожен із них цілеспрямовано підготовлений у своєму сегменті роботи. Функціональні можливості як верхнього, так i нижнього акробатів повинні відповідати професійним вимогам. Це дозволяє досягати якісних результатів, демонструвати високу майстерність. Кількість спортивних акробатичних пар, що з'являються серед циркових артистів нині, уже не один рік поспіль вражає. Причин цьому можна назвати декілька. Але нас цікавить професійна майстерність виконання компонентів номеру: трюкова, хореографічна та акторська. Такі пари демонструють злагодженість та впевненість парної роботи. В багатьох випадках вони пов'язані один з одним довгий час. Їх спортивна підготовка починається в дитячо-юнацькій спортивній школі, де прискіпливо ставляться до всього процесу підготовки та підбору партнерів. Під час спортивних змагань пари демонструють три композиції. Основу кожної 3 цих композицій складають силові, вольтижні, акробатичні вправи та стрибки.

Отже, для виступів у цирку пари обирають той вид акробатики, який їм більше імпонує. Постановка номеру в більшості випадках здійснюється разом 3 режисером або хореографом. Вдачею стає робота з рухливими спортсменами, які, до того ж, здатні виконати акторські завдання. На теренах сучасного циркового простору кожен посідає своє місце. Ті пари, які залишають професійний спорт і приходять у цирк, не стають конкурентами цирковим акробатам. Вони поступово набираються досвіду і згодом стають повноправними членами циркового співтовариства.

Види силової акробатики в цирковому мистецтві представлені майстрами вищого гатунку. Чоловічі пари, 
змішані дуети в своєму арсеналі акробатичних трюків мають вправи $з$ програм спортивної акробатики. Але сама подача їх має зовсім інший характер. В якості прикладів можна назвати відому чоловічу пару крафт-акробатів «Alexis-Brothers» (США), що вражала своєю технікою виконання надскладних трюків. Пара відповідала критеріям циркових акробатів, демонструючи атлетизм та фізичну силу. Елегантна манера, сценічна зовнішність та артистизм - ці компоненти циркового номеру виділяли пару від інших виконавців. Вони тривалий час були взірцем майстерності для акробатичних пар, що починали свій шлях у циркове мистецтво [70].

Надзвичайно талановитими $є$ українські акробати, чоловіча пара силових акробатів, брати Олександр та Сергій Грінченки. Вони пройшли професійну підготовку в аматорській цирковій студії (керівник - О. Крачун). У київському цирковому училищі їх тренером стала Н. Тищенко, відома в минулому спортсменка. Їх навчання було насиченим i різнобічним, що спонукало і режисера Д. Віскова до здійснення оригінальної постановки. В номері братів Грінченків силові акробатичні комбінації виконувались на високому технічному та професійному рівні і доповнювались виразною пластикою, особливим внутрішнім станом. Треба підкреслити, що в багатьох випадках партнери в циркових парах зовнішньо подібні один до одного за зростом і вагою. Якщо партнери дотримуються професійних вимог, володіють технікою виконання акробатичного трюку, тоді в парній роботі не виникає проблем.

Ефектно виглядають пари, в яких партнери майже рівні за зростом демонструють легкість та невимушеність при виконанні акробатичних комбінацій. Такою була чоловіча пара братів Олександра та Дмитра Шаркових (Естонія), яка вражала унікальними надприродними здібностями при виконанні акробатичних елементів. 3 дитинства хлопцями займалися батьки, циркові артисти. Підготовка була спрямована на розвиток фізичних даних дітей, а саме розтяжок, стійок, гнучкості. У подальшому на прийомах балансування 
виконувались напрацьовані парні елементи. Українська змішана акробатична пара «Duo Diving» Валентини Сіденко та Ігоря Гончаренка за довгий час своєї артистичної кар'єри здобула авторитет серед колег і любов глядача. У пару Валентина та Ігор об'єдналися ще під час навчання в цирковому училищі (тренер - Н. Тищенко).

Саме наявність постійної концертної практики надає виступам артистів злагодженості та досконалості, сприяє зростанню професійної майстерності. Серед великої кількості змішаних акробатичних пар виділявся дует Наталії та Віктора Небратів. Свого часу вони спромоглися відродити відсутній у цирку цей вид. Змішана пара, де нижньою є партнерка, одразу викликала інтерес і у глядача, і у циркових продюсерів. Їх номер «Leopardes» (режисер - В. Гнєушев) вразив оригінальним рішенням - артисти увесь виступ проводили з хустинами на обличчях, а пластика нагадувала природну грацію звіра.

Китайський акробатичний дует Ву Женг Дан та Вей Баохуа став всесвітньовідомим завдяки виконанню номеру «Східний Лебідь» на музику 3 балету П.І. Чайковського «Лебедине озеро». Па-де-де Одетти на принца Зігфріда набув акробатично-циркового вирішення. Партнерка в пуантах виконувала складні хореографічно-акробатичні підтримки та елементи. Від технічно вивірених рухів нижнього залежала впевненість та стійкість партнерки. Такий прийом виконання акробатичного номеру не $€$ відкриттям, але наявність індивідуальної манери, рівня хореографічної підготовки, а також постановка відрізняють такі пари між собою.

Поява китайського акробатичного дуету 3 номером «Жага життя» вражає своєю унікальністю. Вперше у світовій практиці циркового мистецтва акробатичний номер виконували артисти 3 обмеженими фізичними можливостями. Юнак нижній акробат, без однієї ноги, впевнено рухався, спираючись на одну милицю. Дівчина - без руки. Глядач був вражений виконанням дуетом хореографічних підтримок, складних акробатичних трюків. 
Циркових пар, у номерах яких базовими є елементи вольтижної акробатики, значно менше.

«Duo Kiss», український акробатичний дует Інни Ваяр та Юрія Процюка, є однією 3 таких пар. За характером їх провідний номер драматичний, у сюжеті відображені напружені стосунки двох молодих людей. Трюки вольтижної акробатики чергуються 3 декількома елементами силової акробатики та підкреслюють цю напругу, додають динамізму. Партнери легко впоралися 3 навантаженням, адже в минулому вони мали достатню спортивну підготовку.

У головному номері українських циркових артистів, чоловічої пари братів В'ячеслава та Олександра Ірошнікових (режисер - Т. Поздняков), елементи силової та вольтижної акробатики були рівноцінними засобами виразності. До цього додавались і окремі акробатичні стрибки. Отже, спортивна та циркова підготовка братів Ірошнікових мали змогу проявитись у цьому номері [34].

Тільки в цирковому мистецтві присутній різновид акробатичного жанру, номери якого відносять до комічного або ексцентричного характеру. Рівень технічної підготовки акробатичних трюків не менш важливий для виконавців таких номерів, ніж наявність комічних, акторських здібностей. Надскладне завдання для циркового артиста-акробата втілення комічних образів, запропонованих режисером. В акторській грі треба досягати невимушеності. Глядач сприймає артиста і жваво реагує на його гру, якщо він стає співучасником діiі. Іноді під час виступів виникають ситуації, коли артистам необхідно проявити імпровізаційні здібності. Наявність такого вміння ще більше розкриває акторський талант виконавців. Серед нових акробатичних пар - акробатично-ексцентрична пара братів Миколи та Андрія Писюра «Duo Twins» (режисер - М.Баранов). Хлопці з дитинства займались у цирковій студії різними жанрами (м. Львів). Під час навчання в Київській муніципальній академії естрадного та циркового мистецтв братів об'єднали в пару. В номері використовуються трюки силової акробатики i декілька відривних елементів, що $\epsilon$ 
допоміжними. Акробати багато рухаються, виразні в пластиці, додають акторської гри. Все органічно пов'язано з музичним матеріалом.

Отже, в акробатичному жанрі циркового мистецтва України пари є однією з цікавих форм діяльності артистів, їх самовираженню на манежі або сценічному майданчику. Вони не поступаються майстерністю представникам інших підвидів акробатичного жанру.

Одна 3 найуспішніших пар у сучасному українському цирковому просторі - «Duo Flash» (Сфрем Біткіне та Євген Дашківський). Мрії його учасників формувалися з дитинства, не без допомоги батьків. Євген Дашківський, нижній - акробат «Duo Flash», походить із сім’ї циркових артистів. Творчий шлях батька мав вплив на вибір майбутньої професії сина, Євгена. Юрій Іванович Дашківський, жонглер, акробат, iз дитинства навчав сина азам циркового мистецтва. Бажання батьків Євгена збулись, коли син вступив на циркове відділення тоді ще КДУЕЦМ. Шлях Єфрема Біткіне, автора даної розвідки, в майбутню професію починався 3 секції спортивної гімнастики. Мета батьків полягала в тому, аби спрямувати енергію юнака на справу, яка заполонить увесь вільний час. До того ж, спортивна гімнастика розвиває фізичні здібності дитини і закладає необхідні підвалини на майбутнє. Такий початок допоміг згодом, коли незабаром батьки привели сина в дитячу циркову студію «Алє-ап». Керівник студії - А. Підгорний, тренери-викладачі - В. Кувшинов, В.В. та В.О. Соболєви, ветерани цирку й естради, займались із дітьми дуже відповідально, готували всіх до роботи в багатьох циркових жанрах. Студія брала участь у новорічних виставах, оглядах дитячих циркових колективів, концертах-звітах та в інших заходах Київського палацу дітей та юнацтва. Багато з учасників студії мріяли про вступ до профільного училища. Діти були зацікавлені у результатах занять заради здійснення мети.

Клоунадою спонукав займатись А.М. Підгорний, побачивши схильність до комічного. А.М. Підгорний, видатний майстер цирку, акробат (верхній), еквілібрист-ексцентрик на 
котушках, кому колись асистував Ю. Нікулін, був професіоналом вищого гатунку. Він ділився своїм досвідом, із великою радістю навчав дітей у студії i своїх студентів в училищі, все своє життя присвятив цирку.

У 1995 р. у КДУЕЦМ майбутніх учасників «Duo Flash» об'єднали в акробатичну пару. Тренером-викладачем було призначено Н.М. Тищенко, видатну спортсменку, заслуженого майстра спорту. «Їх стиль виконання парних вправ відрізнявся легкістю та невимушеністю, гармонійним сполученням акробатики із хореографією. Для тренера робота 3 чоловічою парою стала викликом. Ї̈ї досвід був більше пов'язаний із жіночими акробатичними парами. Отже, студенти і тренер разом натхненно починали нову спільну справу, метою було, окрім індивідуальної фізичної підготовки, досягати злагодженості в парній роботі. Все було складно, але цікаво. Парні вправи засвоювалися спочатку на лонжі. Поступово молоді артисти почали їх виконувати більш впевнено, що дозволяло перейти до самостійної роботи. Артисти вчились відчувати один одного та довіряти діям партнера. Без цих навичок виконувати вольтижні вправи ризиковано. Вже наприкінці першого року навчання пара продемонструвала непогані результати 3 парної акробатики та індивідуальних акробатичних стрибків. Розуміння відповідальності за подальші якісні результати вимагало від учасників дуету виконання нових, усе складніших завдань. Із початком другого навчального року (1996-1997 рр.) до роботи з парою приєднався викладач-хореограф. Індивідуальні заняття проходили з метою розвитку рухливості та координації артистів-початківців. Додаткові вправи на розвиток гнучкості та стрибучості були необхідні для виконання майбутніх акробатичних трюків. Ці заняття виховували витривалість, адже загальні навантаження збільшувалися. Групові та індивідуальні заняття з майстерності актора, танцю, гриму та історії цирку готували учасників дуету до майбутньої професії артиста цирку. 3 третього року навчання (1997-1998 рр.) до роботи 3 парою долучився режисер. Акробатична пара вже мала певний набір трюків, на базі яких 
можна було здійснювати постановку навчального номеру. В планах підготовки пари до випускного шоу тренер передбачала засвоєння артистами пари складніших трюків. Поступово вся творча група рухалась до кінцевого результату. Було приємною несподіванкою для всіх, коли пару, студентів III курсу, запросили до участі в концерті-звіті училища, який відбувся в червні 1998 р. Саме цим виступом пара вперше заявила про себе зі сцени, а успіх надихнув на продовження роботи над номером. Попереду був ще рік навчання, який вимагав мобілізації зусиль. Пара удосконалювала техніку виконання, відпрацьовувала всі компоненти номеру. Робота була виснажливою, але завзятість перемагала. Технічна частина ускладнилася, отже, вводились і корективи до загальної композиції номеру.

3 кожним прогоном номеру уточнювались деталі, які мали важливе значення для створення характерів персонажів, їх логіки поведінки, акторської гри. Танцювальні рухи тісно поєдналися $з$ трюками. Отже, загальне виконання композиції мусило співпадати 3 музичним темпом та відповідати музичному відрізку часу. Ця кропітка робота вимагала від учасників дуету зібраності, фізичних сил. Активна участь у творчому процесі надихала пару. В подальшій кар'єрі ці практичні навички стали при нагоді. Після успішного випускного державного іспиту (червень 1999 р.) дует очікували шоу-звіти. Концерти, які щорічно бажала переглянути велика кількість глядачів, приїхали подивитись представники театріввар'єте, цирків-шапіто та продюсери з Свропи. «Duo Flash» отримав запрошення до участі в програмі Національного цирку України (вересень 1999 - січень 2000 рр.). Півроку роботи поруч із видатними майстрами цирку стали практичною школою на початку творчої кар'єри пари. Вона швидко пристосувалась до умов роботи в манежі, адже композиція номеру була більше розрахована для показу на сценічному майданчику. Разом із режисером хлопці активно шукали шляхи виходу на європейські сцени або міжнародні циркові фестивалі. Першою вдачею стало запрошення взяти участь у фестивалі 
молодих циркових артистів «La Pisteaux Espoiies - 2000» в місті Турнай (Бельгія). Перша нагорода, гран-прі та спеціальні призи, схвальні відгуки преси, членів журі, реакція глядачів усе додало впевненості. Так розпочався довгий творчий шлях акробатичної пари різними країнами світу. За увесь час існування «DuoFlash», а це понад 20 років, дует мав нагоду познайомитись із майстрами цирку та естради багатьох держав, продюсерами та діячами циркового мистецтва, президентами найвідоміших міжнародних циркових фестивалів. «Duo Flash» своїми творчими здобутками і по сьогодні стверджує статус української циркової школи в зарубіжному арт-просторі.

Створення «Duo Flash» як акробатичної пари відбулося, коли партнери досягли вже досить дорослого віку. Порівняно зі спортивними акробатичними парами, професійний досвід яких довший, пара набагато в чому відставала. Спортивні акробати починають набувати навичок у дитячо-юнацьких спортивних школах. Усе спрямовано на досягнення високих спортивних результатів. У випадку «Duo Flash» орієнтири в роботі були визначені у напрямку творчих здобутків в цирковому мистецтві. Не виключалась необхідність підготовки і парних акробатичних вправ вищого рівня складності, наприклад, сальто 3 плечей в плечі, пірует із плечей на підлогу, подвійне сальто, т.ін. Робота 3 тренером-викладачем мала за мету виховати у майбутніх артистів віру і впевненість. Постійний контакт із майстром, їі наполегливість досягали бажаного результату. Дует докладав багато зусиль заради майбутніх успіхів. Послідовність у вивченні акробатичних вправ, терпіння та працездатність були головними чинниками на початку спільної роботи. Викладач Н.М. Тищенко вибудовувала тренувальний процес, враховуючи функціональні можливості студентів. Вони багато часу проводили на лонжі, адже саме 3 цього починаються вивчення парних вольтижних вправ. Кожний елемент має технічні особливості виконання. Від початківців вимагали ретельного засвоєння саме цих особливостей. Тільки 3 дозволу тренера студенти мали можливість перейти до самостійного виконання вправ без лонжі. Аби уникати зайвих травм та помилок, хлопці 
продовжували бути в тісному контакті 3 тренером. Творчу діяльність акробатичної пари було вирішено спрямувати в ексцентричному жанрі. Це відповідало їхнім характерам, природнім та фізичним здібностям. Тому таке рішення тренеравикладача вони підтримали і майбутню роботу планували, дотримуючись певних вимог.

В індивідуальний план підготовки входили вправи на підтримання та розвиток функціональних даних як нижнього, так і верхнього акробатів. Такі завдання були поставлені перед ними 3 самого початку діяльності пари. Від якості засвоєння трюкового репертуару залежав кінцевий результат їх виконання. Тому ставлення акробатів до цих вимог було відповідальним. Окремо вони приділяли багато уваги акробатичним стрибкам, що розширювали їх можливості. Згодом результати спільної роботи за перший рік навчання (1995-1996 рр.) були продемонстровані на іспиті. Схвальні відгуки сприяли зміцненню віри в майбутнє акробатичної пари. Хлопці визначили для себе 3 головні принципи в роботі: самовіддача, самодисципліна та самоконтроль. Нові завдання тренера спонукали до активних дій у роботі. Блок профільних дисциплін був розрахований на професійну підготовку майбутніх артистів цирку. До нього додавались індивідуальні години для роботи з хореографом та режисером. До занять із акробатики додались штудії з хореографії.

Почався новий етап формування дуету. Трюковий репертуар, запропонований тренером, вимагав від артистів напрацювання злагоджених дій у парі. Хореографія розвивала здібності координувати свої рухи, уміння підкоряти їх певному темпу i ритмічному малюнку. Виконання хореографічних вправ вимагало від артистів витривалості, контролю над власними діями. Бачення майбутньої композиції формувалось в уяві режисера, хореографа протягом досить тривалого часу. Адже саме від готовності пари демонструвати весь трюковий репертуар, впевненості при виконанні залежала робота режисера та хореографа. 3 трюків формувались певні комбінації, які слід було виконувати злагоджено. Виконавці 
вчилися перемагати хвилювання, набували сценічної майстерності.

Особливість роботи режисера в цирковому номері студентів цілком залежить від їх готовності бути задіяними в творчому процесі. Це особливий період стосунків між режисером та виконавцями, коли досягається порозуміння між усіма учасниками творчого колективу. Взаємодія партнерів в експозиції номеру завершується акробатичним трюком. Цікавим є перехід від першої до другої частини музичної теми. Він з'являється в темі несподівано і задає діям виконавців більшої емоційності. Отже, всі рухи та поведінка виконавців пов'язані ритмом, жвавим темпом і особливим жартівливим настроєм, який присутній у музиці. Саме ці відчуття режисер передав виконавцям. На цьому аспекті п'єси робився акцент, у якому розвиток дії набував яскравого вираження. В композиції поступово збільшувалась кількість акробатичних трюків, каскадних комбінацій. Вони поєднувались між собою танцювальними рухами. Акторська гра між партнерами створювала необхідну атмосферу. Виступи «Duo Flash» глядач сприймав жваво, підтримуючи оплесками. Відбувався контакт iз залом, який заряджав виконавців. Емоції, кураж при виступі поверталися від глядача 3 подвійною силою. Весь час, до останнього акорду в музиці і до останнього стрибка, який артисти виконують у фіналі (рондад - заднє сальто), глядач $\epsilon$ співавтором процесу, емоційно активним учасником. Режисерхореограф та виконавці досягли мети і створили ігрову ситуацію, посиливши її виразність багатьма засобами. Перший варіант концертних костюмів і грим підкреслювали жартівливі образи. Їх яскраві червоно-жовті кольори відповідали загальному настрою, присутньому в номері. Вже згодом зовнішній вигляд артистів змінився на більш класичний за стилем, але це не зруйнувало ідеї номеру. Їх образи набули більшої зрілості. Саме з такими змінами концепція номеру набула іншого характеру та завершеності. Незвичний варіант номеру, без використання реквізиту та представлений дуетом як акробатично-ексцентричний, сприймався по-різному. В 
багатьох програмах театрів-вар'єте та цирків-шапіто Європи «Duo Flash» представляли як акробатів-коміків, як танцювально-акробатичних каскадерів, як акробатівексцентриків. При цьому дует завжди зберігав свою індивідуальність.

3 першої появи на манежі Київського державного цирку акробатично-ексцентрична пара «Duo Flash» завоювала прихильність колег-артистів. Це надавало впевненості. За півроку роботи молодих артистів у Києві творче об'єднання «Укрдержцирк» не проявило зацікавленості в їх роботі. «Duo Flash» самостійно шукав шляхи реалізації свого майбутнього творчого існування, 3 допомогою лише свого режисеранаставника. Завдячуючи його зусиллям, дует вперше було запрошено на Міжнародний фестиваль молодих артистів цирку «La Piste aux Espoirs - 2000» в місті Турнай (Бельгія). Виступ дуету здійснив фурор як серед членів журі, так і серед глядачів. Серед усіх учасників фестивалю «Арена надій» найбільший резонанс викликав саме виступ «Duo Flash». Бельгійські газети рангу «La Courrier de l'Egcau» та «La Derniere Heure» висвітлювали цю подію.

Участь дуету в фестивалі молодих артистів цирку «European Youth Circus» відбулась також завдяки режисерові. Фестиваль проходив у Вісбадені (Німеччина) восени 2002 р. Спеціальний приз фестивалю не дуже втішив артистів. Але фото з виступу дуету на фестивалі, яке з'явилось на обкладинці відомого журналу «Kaskade» (№61, січень, 2001 р.), пізніше компенсувало витрачені емоції. Одразу після успіху на фестивалі у Турнаї вони отримали перші контракти: до Франції - від продюсера Жака Де Лануа, в шоу «Lesspectacles Du Monde» (грудень, 2000 р.), та у програму відомого німецького цирку «Кроне» (м. Мюнхен, Німеччина, грудень 2000 р. січень 2001 р.). Запрошення до німецького цирку дует отримав особисто від пана Урса Пілса, який бачив успішний виступ українців у м. Турнаї і висловив свої приємні враження. Така підтримка для артистів-початківців на старті кар'єри була вкрай необхідна. «Duo Flash», єдиний представник українського 
циркового мистецтва в міжнародній програмі, мав змогу виступати разом із Крістел Зембах-Кроне, представницею відомої західноєвропейської циркової династії.

Перші гастролі пари містами Франції та дебютні виступи в цирку «Кроне» мали великий успіх. У цирку «Кроне» дует уперше виступали під супровід оркестру. Це їх не дуже вразило, адже фонограма звучала яскравіше і мала емоційнший вплив на виконавців і на глядача. 32001 р. для дуету почалось активне творче життя. Контракти на роботу на сценах театріввар'єте Німеччини підписувались за рік наперед. Отже, «Duo Flash» у квітні-травні 2001 р. розпочав виступи в м. Дюсельдорф, де знаходиться відоме «Roncalli's Apollo Variete» (директор - Бернард Пауль). Участь в одній програмі з відомим коміком, цирковим артистом Конрадом Турано, якому на той час виповнився 91 рік, було великою честю. Дуету випала можливість контактувати $з$ живою легендою німецького цирку та переймати досвід акторської майстерності. Вміння Турано спілкуватись із глядачем, взаємодіяти 3 партнером (сином, Джонні), для них стало прикладом професіоналізму вищого гатунку. У програмі виступали колумбійський комік-акробат на батуті Ніколь Дубан, американський комік-мім Елан, та інші відомі артисти, чий досвід сценічної роботи також молоді українські артисти переймали з вдячністю.

На початку вересня 2001 р. «Duo Flash» випала нагода отримати ангажемент у славетне вар'єте «Winter garten», у Берліні. У шоу-виставі «Nachtgestalten» вони виступали разом із відомим в Свропі ілюзіоністом-коміком Свгеном Вороніним, українським артистом, киянином. Такі зустрічі в одній програмі 3 земляками були приємними подіями. Завдяки С. Вороніну відбулося знайомство 3 видатними українськими боксерами, Володимиром та Віталієм Кличками, які відвідали шоупрограму. В 2006 р. пара отримала другий контракт у вар'єте в шоу-виставі «Lollipop». Режисером-постановником обох вистав був Бернард Пауль.

Попереду «Duo Flash» очікувала участь у міжнародному фестивалі циркового мистецтва в м. Будапешт (Угорщина). Ця 
подія відбулась у січні 2002 р. і принесла срібну нагороду. Також дует отримав приз від цирку «Ringling Brosersend Barnum/Bailey», який вручав член журі Тім Холст (США). Контракт на роботу у театрі «Yoshimoto Kogyo Fondation» у м. Осака (Японія) вручав член журі Хіроакі Хаяші. Своєю перемогою на дорослому фестивалі українські артисти довели скептикам, що номер дуету в такому варіанті має право на існування. За всіма ознаками він $є$ сучасним цирковим номером. Члени журі фестивалю Леонід Костю та Максим Нікулін (Росія) щиро вітали артистів 3 успішним виступом. Вони поступово рухалися вперед, аби ввійти до когорти відомих артистів європейського сучасного циркового мистецтва. Для кожного циркового артиста визнання на фестивалях вищого рівня $\epsilon$ важливим етапом у творчому житті.

«Duo Flash» продовжив виступи на багатьох сценах вар'єте Німеччини, в театрі японської Осаки, в програмі відомого цирку «Конеллі» у Цюріху (Швейцарія). У 2019 р. вони мали нагоду вдруге брати участь у різдвяній програмі цирку «Конеллі».

Треба відзначити, що на початку кар'єри «DuoFlash» найчастіше брав участь у програмах театрів-вар'єте Німеччини. Головним чином це стосувалося агенції «GOP Entertaiment». 3 Німеччини дует виїжджав на гала-шоу Європою (Італія, Кіпр, Нідерланди, Португалія). Дует був двічі запрошений до Аргентини для участі в шоу на телебаченні, виступали артисти в державах Ближнього Сходу (Кувейт, ОАЕ, Саудівська Аравія).

Незабутньою за емоціями та враженнями подією стала участь дуету в конкурсі «Traumtanzer». Він проводився каналом «Культура» на німецькому телебаченні в м. Кассель (серпень 2003 р.). Фестиваль був популярним у Німеччині серед глядачів, бо вони безпосередньо брали участь у голосуванні за кращий номер або найкращого виконавця. Цікавим було те, що «Duo Flash» треба було змагатись із відомими європейськими артистами. До складу сильних конкурентів входили й українські артисти цирку. 325 номерів конкурсної програми 
7 представляли українські виконавці. «Duo Flash» вийшов до фіналу, який проходив за участі журі. Серед них був Домінік Маклєр, директор-розпорядник «Fectival Mondial du Cirquede Demain» (м. Париж). Це була не перша зустріч пари 3 паном Д. Маклером. Саме в Касселі «Duo Flash» отримав запрошення до участі у фестивалі «Цирк завтрашнього дня» в Парижі. Такий перебіг подій надихав, став стимулом у подальшій роботі. Графік виступів був дуже щільним. За рахунок стабільної роботи артисти набували досвід та підтримували фізичну i професійну форму. Вся діяльність була сконцентрована на підготовці до участі у фестивалі. В кожній програмі театріввар'єте 3 артистами працював режисер-постановник шоу. Підготовка до прем'єри проходила в стислі терміни. Від творчої активності кожного артиста, його самодисципліни та самовіддачі залежав загальний результат. У деяких випадках хлопці були задіяні як актори, що додавало їм авторитету в очах режисерів і викликало повагу у керівників вар'єте.

У лютому 2004 р. відкрився XXV фестиваль «Цирк завтрашнього дня». Відомий французький цирк «D’HiverBouglione» довгий час був місцем проведення конкурсних змагань найкращих молодих артистів цирку 3 усього світу. В попередні роки багато українських виконавців починали циркову кар'єру з участі саме в цьому фестивалі. Цього разу Україну представляли 5 циркових номерів. Участь у фестивалях має особливе значення у творчій біографії кожного артиста. У складі журі фестивалю був представник України - лауреат, володар золотої медалі (1998р.) Анатолій Залевський. За результатами конкурсу «Duo Flash» став лауреатом та здобув бронзову медаль, отримавши і 2 спеціальні призи.

Українська акробатична пара «Duo Flash» залишила своє ім'я в історії ще одного фестивалю. За перші 6 років творчої діяльності «Duo Flash» спромігся утвердитися серед артистів європейського та світового рівня. Зустріч із паном Д. Маклером залишила добру пам'ять про нього як про людину і фаната циркового мистецтва, який доклав чимало зусиль, аби сучасний цирк розвивався. В українській пресі 3'явились публікації 3 
нагоди перемоги артистів на фестивалі, де рекламувався їх тріумф, - 4 золоті медалі, 2 бронзові та 2 спеціальні призи... 2 бронзові нагороди у акробатів-ексцентриків Сфрема Біткіне та Євгена Дашківського (режисер і викладач - Олексій Біткіне, батько Єфрема, який за рік розробив композицію 3 карколомних подвійних сальто).

Несподівана ситуація дозволила «Duo Flash» побувати на гастролях і в Греції. На сцені відомого афінського театрувар'єте «Яліно-театро» було представлено шоу-програму «Балаган».

2008 p. «Duo Flash» розпочав 3 участі у XXXII міжнародному цирковому фестивалі в Монте-Карло. Виступ був вдалим, дует отримав спеціальний приз. Серед учасників були й інші українські артисти, акробати на балонах під керівництвом О. Рибченка.

Географія гастролей дуету розширювалась. Так, восени того ж року пара взяла участь у вуличному фестивалі в м. Шізуоко (Японія). За 9 років існування «Duo Flash» гастролі Німеччиною пройшли майже на всіх сценах театрів-вар'єте. Дует працював із відомими артистами в різних шоу i y виставах, підготовку яких здійснювали талановиті режисери.

Країною, в якій провела тривали час і здобула великий життєвий і творчий досвід, стала Іспанія, куди артистів запросили для подальшої роботи. Вперше «Duo Flash» став учасником еротичного шоу «The Hole» («Дірка», 2011 р.), в якому поєднувались бурлеск та вокал, циркові та хореографічні номери. Шоу мало успіх, і досить довгий час, до 2016 р., трупа гастролювала багатьма містами Іспанії, побувала на Канарах i на Майорці, викликаючи аншлаги. Запрошення для участі у XVIII міжнародному цирковому фестивалі в м. Латина (Італія, 2016 р.) стало для дуету викликом. Пара дала згоду. Їх поява серед учасників фестивалю викликала здивування у членів журі, адже серед них були вже знайомі їм Урс Пілс, Іштван Кріштоф, Петро Дубинський, Борис Федотов. Україну представляв Микола Кобзов. «Duo Flash» виборов III місце, став лауреатом і володарем бронзових нагород. 
Творчою вдачею стала участь дуету у шоу-виставі «Цирк 1903 - золотий вік цирку». Організатори шоу-вистави стали ініціаторами світового турне. Воно розпочиналось із Австралії (грудень 2016 - січень 2017 рр.), у Канберрі, Мельбурні та Сіднеї. Чудові сценічні майданчики театрів, особливо в знаменитій «Opera-House», бурхливі оплески глядачів вражали i надихали. Учасники пари мали нагоду зустрітися 3 відомим радянським артистом цирку, клоуном, заслуженим артистом УРСР, Олександром Діаманді, який багато років проживає в Австралії. Про успішні гастролі сповіщала газета української діаспори. Турне продовжилось у США. Шоу-виставу подивились тисячі глядачів у багатьох містах Північної Америки. В Нью-Йорку виступи трупи відбувались у всесвітньовідомому залі «Medison Square Garden».

Висновки. У 2019 р. «Duo Flash» отримав запрошення до ювілейної шоу-програми «Internationales Variete Theater» «Tiger Palast» у Франкфурт-на-Майні. Пара повернулася в Німеччину. А незабаром, повернувшись до Києва (березень 2019 р.), артисти отримали й запрошення до участі у програмі Національного цирку України. «Duo Flash» з’явився на манежі славетного цирку. 20 років потому відбулося повернення на манеж пари, для якої там розпочалось довге творче життя. На цьому творчий шлях «Duo Flash» не завершився. Партнери разом крокують вперед, зберігаючи творчі, людські, дружні стосунки між собою. Це ще одне досягнення, яке акробатичноексцентричний «Duo Flash» залишить по собі в історії вітчизняного, європейського та світового циркового мистецтва.

\section{Література}

1. Гуревич 3. Цирковая терминология. Москва: Искусство, 1982. 44 с.

2. Гуревич 3. О жанрах советского цирка. Москва: Искусство. 1984. 303 с. 
3. Гур'єва О. Витоки виникнення основних жанрів циркового мистецтва: практ. порадник. Маріуполь: Рената, 2009. 240 с.

4. Дмитриев Ю. Советский цирк. Москва: Искусство, 1963. $400 \mathrm{c}$.

5. Дмитриев Ю. Русский цирк. Москва: Искусство, 1953. $262 \mathrm{c}$.

6. Запашный В. Вольтижная акробатика. Москва: Искусство, 1961. 131 с.

7. Кожевников С. Акробатика. Москва: Искусство, 1984. $140 \mathrm{c}$.

8. Коркин В. Акробатика. Москва: Физкультура и спорт, 1983. $167 \mathrm{c}$.

9. Романенкова Ю. Сучасна українська циркова школа як інструмент презентування країни у світовому культурному просторі. Молодий вчений. 2020. Вип. 3(79). Сс. 69-73.

10. Романенкова Ю., Ганзюк В., Игнатов А. Эксперименты молодых артистов в жанре парного ручного эквилибра в контексте развития украинского проекта «Raw цирк». Наука, исследования, развитие. 2018. Вып. 3. Сс. 27-33.

11. Романенкова Ю., Вишневский П., Литвиненко М. Пантомима в современном украинском сценическом искусстве: возможности для самореализации артистов молодой генерации. Розвиток сучасної освіти i науки: Результати, проблеми, перспективи. Аксіологічні аспекти в розвитку науки та освіти. Конін-УжгородХерсон-Кривий Ріг, 2018. Сс. 43-45.

12. Романенкова Ю. К вопросу о месте цирковедения в современной украинской гуманитаристике. Сучасні тенденції розвитку науки. Ужгород, Херсон, 2018. Сс. 150-153.

13. Романенкова Ю. Цирковое искусство как культурный маркер современной Украины. Science, research, development. Warszawa, 2018. Pp. 150-153.

14. Шнее А., Славский Р. Маленькая энциклопедия. Цирк. Москва: Советская энциклопедия, 1973. 447 с. 
15. Шумакова С. Генезис і еволюція харківської школи циркового мистецтва: автореферат дис. ... канд. мистецтвознав.: 26.00.04. Харків, 2015. 20 с.

16. Romanenkova J., Paliychuk A., Sharykov D., Bratus I., Kuzmenko H., Gunka A. Circus art in modern realities: functions, problems, prospects. Revista inclusiones. 2020. Vol. 8. Pp. 571-581.

\section{Ефрем Алексеевич БИТКИНЕ, независимый исследователь, Киев, Украина, e-mail: artplatforma88@gmail.com, ORCID: 0000-0003-4396-4849}

\section{ЭКСЦЕНТРИЧЕСКАЯ АКРОБАТИЧЕСКАЯ ПАРА КАК ФЕНОМЕН СОВРЕМЕННОГО ЦИРКОВОГО ИСКУССТВА (НА ПРИМЕРЕ ДУЭТА «DUО FLASH»)}

Аннотация. Современное цирковое искусство Украины исторически связано с деятельностью и акробатов-скоморохов, и первых профессиональных артистов цирковых трупп. Особое место занимают акробатические пары. Отдельно выделим именно эксцентриков, комиков. Неоценимым опытом для молодого поколения цирковых артистов в акробатическом жанре являются достижения братьев Александра и Василия Яловых, супругов Пастуховых, братьев Маренковых, братьев Дьяковых и др. Они стояли у истоков циркового акробатического искусства еще советской Украины. Спорт и искусство цирка всегда дополняли друг друга в развитии акробатики как в манеже, так и на спортивных площадках. Тесная связь наблюдается и в творческой деятельности современных цирковых артистов-акробатов, а именно, среди прыгунов в групповых номерах, мужских и смешанных парах, женских тройках или в мужских четверках, в других видах акробатического жанра. На сегодня есть много примеров именно акробатических шоу или спектаклей в мировом цирковом искусстве. 
Акробатическая представление в цирке - это актуальная и современная форма зрелища. Главным действующим лицом спектакля является артист-акробат, владеющий различными разновидностями этого жанра. Спектакль по своей форме может быть дивертисментом, шоу, ревю, спектаклем с драматургическим сюжетом.

К самым значительным феноменам современного украинского циркового искусства сегодня можно отнести акробатически-эксцентрическую пару «Duo Flash», имеющую более 20 лет истории. Дуэт является не только самостоятельным явлением циркового пространства Украины, но и имеет особое значение для позиционирования современного украинского цирка за пределами страны, то есть выполняет важную функцию улучшения имиджа Украины в мировом культурном поле, является инструментом построения межкультурного диалога. Участни дуэта - Ефрем Биткине и Евгений Дашковский, представители цирковых династий, выпускники Киевской муниципальной академии эстрадного и циркового искусств. Данная статья посвящена основным периодам их творческой биографии (киевскому, немецкому, испанскому), становлению как акробатической пары, взаимообогащению традиций разных цирковых школ на их примере.

Ключевые слова: цирковое искусство, акробатика, эксцентрика, акробатическая пара, фестиваль, режиссер, тренер 


\author{
Yefrem O. BITKINE, \\ independing researcher, \\ Kyiv, Ukraine, \\ e-mail: artplatforma88@gmail.com, \\ ORCID: 0000-0003-4396-4849
}

\title{
ECCENTRIC ACROBATIC COUPLE AS A PHENOMENON OF MODERN CIRCUS ART (ON THE EXAMPLE OF A DUET "DUO FLASH")
}

\begin{abstract}
The modern circus art of Ukraine is historically associated with the activities of both acrobats, buffoons, and the first professional circus troupes. Acrobatic couples have a special place. We will especially highlight the eccentrics, comedians. An invaluable experience for the young generation of circus artists in the acrobatic genre are the achievements of the brothers Olexander and Vasyl' Yalovi, the spouses Pastukhovs, the Marenkov brothers, the Dyakov brothers, etc. They stood at the origins of circus acrobatic art already in Soviet Ukraine. Sport and circus art have always complemented each other in the development of acrobatics both in the arena and on the sports grounds. A close connection is also observed in the creative activity of modern circus acrobatic artists, namely, among jumpers in group numbers, men's and mixed pairs, women's triplets or men's fours, in other types of acrobatic genre. Today there are many examples of acrobatic shows or performances in the world circus art.

Acrobatic circus performance is an up-to-date and contemporary form of spectacle. The main protagonist of the performance is an acrobat artist, who owns various varieties of this genre. A performance in its form can be a divertissement, show, revue, performance with a dramatic plot.

The most significant phenomena of modern Ukrainian circus art today include the acrobatic-eccentric pair "Duo Flash", which has more than 20 years of history. The duet is not only an special phenomenon in the circus space of Ukraine, but is also of particular importance for the positioning of the modern Ukrainian circus
\end{abstract}


outside the country, that is, it performs an important function of improving the image of Ukraine in the world cultural field, is a tool for building intercultural dialogue. Duet members - Yefrem Bitkine and Yevgen Dashkivs'ky, representatives of circus dynasties, graduates of the Kyiv Municipal Academy of Circus and Performing Arts. This article is dedicated to the main periods of their creative biography (Kyiv, German, Spanish), the formation as an acrobatic couple, the mutual enrichment of the traditions of different circus schools by their example.

Key words: circus art, acrobatics, eccentrics, acrobatic couple, festival, director, coach

\section{References}

1. Gurevich, Z. (1982). Tsirkovaya terminologiya [Circus terminology]. Moscow: Iskusstvo [in Russian].

2. Gurevich, Z. (1984). O zhanrakh sovetskogo tsirka [On the genres of the Soviet circus]. Moscow: Iskusstvo [in Russian].

3. Hur"yeva, O. (2009). Vytoky vynyknennya osnovnykh zhanriv tsyrkovoho mystetstva [Origins of the main genres of circus art]: prakt. poradnyk. Mariupol': Renata [in Ukrainian].

4. Dmitriyev, Yu. (1963). Sovetskiy tsirk [Soviet citcus]. Moscow: Iskusstvo [in Russian].

5. Dmitriyev, Yu. (1953). Russkiy tsirk [Russian citcus]. Moscow: Iskusstvo [in Russian].

6. Zapashnyy, V. (1961). Vol'tizhnaya akrobatika [Vaulting acrobatics]. Moscow: Iskusstvo [in Russian].

7. Kozhevnikov, S. (1984). Akrobatika [Acrobatics]. Moscow: Iskusstvo [in Russian].

8. Korkin, V. (1983). Akrobatika [Acrobatics]. Moscow: Fizkul'tura i sport [in Russian].

9. Romanenkova, YU. (2020). Suchasna ukrayins'ka tsyrkova shkola yak instrument prezentuvannya krayiny u svitovomu kul'turnomu prostori [Modern Ukrainian circus school as a tool for presenting the country in the world cultural space]. Molodyy vchenyy, 3(79), 69-73 [in Ukrainian]. 
10. Romanenkova, YU., Ganzyuk, V., Ignatov, A. (2018). Eksperimenty molodykh artistov $\mathrm{v}$ zhanre parnogo ruchnogo ekvilibra v kontekste razvitiya ukrainskogo proyekta "Raw tsirk" [Experiments of young artists in the genre of pair hand balancing in the context of the development of the Ukrainian project "Raw circus"]. Nauka, issledovaniya, razvitiye, 3, 27-33 [in Russian].

11. Romanenkova, YU., Vishnevskiy, P., Litvinenko, M. (2018). Pantomima v sovremennom ukrainskom stsenicheskom iskusstve: vozmozhnosti dlya samorealizatsii artistov molodoy generatsii [Pantomime in modern Ukrainian stage art: opportunities for self-realization of artists of the young generation]. Rozvytok suchasnoyi osvity i nauky: Rezul'taty, problemy, perspektyvy. Aksiolohichni aspekty $\mathrm{v}$ rozvytku nauky ta osvity. KoninUzhhorodKherson-Kryvyy Rih, 43-45 [in Ukrainian].

12. Romanenkova, YU. (2018). K voprosu o meste tsirkovedeniya $\mathrm{v}$ sovremennoy ukrainskoy gumanitaristike [To the question of the place of circus studies in modern Ukrainian humanitie]. Suchasní tendentsiî rozvitku nauki. Uzhgorod, Kherson, 150-153 [in Russian].

13. Romanenkova, YU. (2018). Tsirkovoye iskusstvo kak kul'turnyy marker sovremennoy Ukrainy [Circus art as a cultural marker of modern Ukraine]. Science, research, development. Warszawa, 150-153 [in Russian].

14. Shneye, A., Slavskiy, R. (1973). Malen'kaya entsiklopediya. Tsirk [Little encyclopedia. The circus]. Moscow: Sovetskaya entsiklopediya [in Russian].

15. Shumakova, S. (2015). Henezys i evolyutsiya kharkivs'koyi shkoly tsyrkovoho mystetstva [Genesis and evolution of the Kharkiv school of circus art]: avtoreferat dys. ... kand. mystetstvoznav.: 26.00.04. Kharkiv [in Ukrainian].

16. Romanenkova, J., Paliychuk, A., Sharykov, D., Bratus, I., Kuzmenko, H., Gunka, A. (2020). Circus art in modern realities: functions, problems, prospects. Revista inclusions, 8, 571-581 [in English]. 